\title{
Mesenchymal Stromal Cells Derived from Bone Marrow and Adipose Tissue: Isolation, Culture, Characterization and Differentiation
}

\author{
Gileade P. Freitas ${ }^{1}$, Alann T. P. Souza ${ }^{1}$, Helena B. Lopes ${ }^{1}$, Rayana L. B. Trevisan ${ }^{1}$,
}

Fabiola S. Oliveira ${ }^{1}$, Roger R. Fernandes ${ }^{1}$, Fernanda U. Ferreira ${ }^{2}$, Felipe A. Ros ${ }^{2}$, Marcio M. Beloti ${ }^{1}$ and Adalberto L. Rosa ${ }^{1, *}$

1Bone Research Lab, School of Dentistry of Ribeirão Preto, University of São Paulo, Ribeirão Preto, SP, Brazil; ${ }^{2}$ Hemotherapy Center of Ribeirão Preto, University of São Paulo, Ribeirão Preto, SP, Brazil

*For correspondence: adalrosa@forp.usp.br

[Abstract] Since their discovery, mesenchymal stromal cells (MSCs) have received a lot of attention, mainly due to their self-renewal potential and multilineage differentiation capacity. For these reasons, MSCs are a useful tool in cell biology and regenerative medicine. In this article, we describe protocols to isolate MSCs from bone marrow (BM-MSCs) and adipose tissues (AT-MSCs), and methods to culture, characterize, and differentiate MSCs into osteoblasts, adipocytes, and chondrocytes. After the harvesting of cells from bone marrow by flushing the femoral diaphysis and enzymatic digestion of abdominal and inguinal adipose tissues, MSCs are selected by their adherence to the plastic tissue culture dish. Within 7 days, MSCs reach $70 \%$ confluence and are ready to be used in subsequent experiments. The protocols described here are easy to perform, cost-efficient, require minimal time, and yield a cell population rich in MSCs.

Keywords: Adipose tissue, Adipocyte, Bone, Bone marrow, Cell culture, Chondrocyte, Mesenchymal Stromal cell, Osteoblast

[Background] The concept of stem cells dates back to the $19^{\text {th }}$ century, but their existence was confirmed in the 1960s and 1970s following experiments by Friedenstein and collaborators, which showed the presence of stem cells in the bone marrow (Friedenstein, 1970; Bianco et al., 2008). Afterward, Caplan (1991) named them as mesenchymal stem cells (here, called mesenchymal stromal cells-MSCs) and proposed their use in regenerative medicine. In the bone marrow, the percentage of MSCc is estimated to be 0.001 to $0.01 \%$ of the total mononuclear cells. Because of their scarcity, alternative sources have been described, although bone marrow remains as the main source of MSCs (Nancarrow-Lei et al., 2017). Adipose tissue is a very promising source because it contains a large number of MSCs that are relatively easy to harvest with minimal discomfort and risk for donors (Zuk et al., 2001). The protocols used to harvest and culture MSCs from either bone marrow (BM-MSCs) or adipose tissue (AT-MSCs), may vary among different species or even among different strains of the same species. The most commonly used methods for obtaining MCSs involve using flow cytometry (Schrepfer et al., 2007), multipotent adult progenitor cell media (Harting et al., 2008), the ficoll-paque gradient centrifugation method (Pierini et al., 2012), and immunomagnetic beads (Wadajkar et al., 2014). Here, we describe cost-efficient protocols that are relatively easy and fast to perform and can be used 
to obtain cell populations rich in MSCs from bone marrow and adipose tissues. These protocols can be used to study several cellular and molecular aspects of MSCs, such as their proliferation, differentiation, and signaling pathways (Abuna et al., 2016; Fideles et al., 2019), the biological effects of growth factors and drugs on MSCs (Oliveira et al., 2012; Zhang et al., 2017), the interactions between MSCs and natural or synthetic biomaterials (Hu et al., 2018; Lopes et al., 2019), and the application of MSCs in regenerative medicine strategies (Almeida et al., 2019; Freitas et al., 2019).

\section{Materials and Reagents}

1. Sterile surgical drape

2. Aluminum foil

3. Coat (ProtDesc, catalog number: 80404440020$)$, storage temperature: RT

4. Mask (ProtDesc, catalog number: 80404440006), storage temperature: RT

5. Cap (ProtDesc, catalog number: 80404440004), storage temperature: RT

6. Gloves (Maxitec, Kevenol, catalog number: 80748910002 ), storage temperature: RT

7. 20-ml syringe (BD Plastipak, catalog number: 990687), storage temperature: RT

8. $21 \mathrm{G}$ needle (BD PrecisionGlide, catalog number: 300054 ), storage temperature: RT

9. Glass tissue culture dish (Pyrex, catalog number: HX0004-00376), storage temperature: RT

10. Corning ${ }^{\circledR} 75 \mathrm{~cm}^{2}$, U-Shaped canted neck cell culture flask with vent cap (Corning, catalog number: $430641 \mathrm{U}$ ), storage temperature: $15 / 30{ }^{\circ} \mathrm{C}$

11. 24 -well cell culture plates (Corning, catalog number: 3524 ), storage temperature: $15 / 30{ }^{\circ} \mathrm{C}$

12. 12 -well plates (Corning, catalog number: 3512 ), storage temperature: $15 / 30{ }^{\circ} \mathrm{C}$

13. 6-well culture plates (Corning, catalog number: 3335 ), storage temperature: $15 / 30{ }^{\circ} \mathrm{C}$

14. 50-ml conical tube (Sarstedt, catalog number: 62.547 .254 ), storage temperature: $15 / 30{ }^{\circ} \mathrm{C}$

15. Microtube 1.5-ml (Eppendorf, catalog number: Z606340), storage temperature: RT

16. Micropipette tips (Eppendorf, catalog numbers: 0030000811/0030000854/0030000870/0030000919), storage temperature: RT

17. Ultra-low attachment, 96-well (Costar, catalog number: CLS7007), storage temperature: $15 / 30^{\circ} \mathrm{C}$

18. Alpha minimum essential medium ( $\alpha-M E M)$ (Thermo Fisher Scientific, catalog number: $12000-$ 022), storage temperature: $2 / 8^{\circ} \mathrm{C}$

19. Dulbecco's modified Eagle's medium (D-MEM) (Thermo Fisher Scientific, catalog number: 12100-046), storage temperature: $2 / 8^{\circ} \mathrm{C}$

20. Dulbecco's phosphate-buffered saline (PBS) (Thermo Fisher Scientific, catalog number: 21600 010), storage temperature: $15 / 30^{\circ} \mathrm{C}$

21. Sodium bicarbonate (Sigma-Aldrich, Sigma, catalog number: S5761-1KG), storage temperature: $15 / 30^{\circ} \mathrm{C}$

22. Gentamycin reagent solution (Thermo Fisher Scientific, catalog number: 15710-064), storage temperature: $-20 /-5^{\circ} \mathrm{C}$ 
23. Penicillin-Streptomycin (Thermo Fisher Scientific, catalog number: 15140-122), storage temperature: $15 / 30^{\circ} \mathrm{C}$

24. Dexamethasone (Sigma-Aldrich, catalog number: D8893), storage temperature: $2 / 8{ }^{\circ} \mathrm{C}$

25. FBS qualified fetal calf serum (Thermo Fisher Scientific, catalog number: 12657-029), storage temperature: $-10^{\circ} \mathrm{C}$

26. Amphotericin B $250 \mu \mathrm{g} / \mathrm{ml}$ (Thermo Fisher Scientific, catalog number: 15290-018, storage temperature: $-20 /-5^{\circ} \mathrm{C}$ )

27. $0.25 \%$ Trypsin (1x) (Thermo Fisher Scientific, catalog number: 15050-057), storage temperature: $-20 /-5^{\circ} \mathrm{C}$

28. Collagenase type II lyophilized (Thermo Fisher Scientific, catalog number: 17101-015), storage temperature: $2 / 8^{\circ} \mathrm{C}$

29. $2.5 \%$ Chlorhexidine (Bioflora Manipullarium), storage temperature: RT

30. $\beta$-Glycerophosphate disodium salt pentahydrate $98.0 \%$ (NT) (Sigma-Aldrich, catalog number: 50020-100G), storage temperature: $2 / 8^{\circ} \mathrm{C}$

31. L-Ascorbic acid (Sigma-Aldrich, catalog number: $33034-100 \mathrm{G}$ ), storage temperature: $15 / 30{ }^{\circ} \mathrm{C}$

32. Ethanol $96 \%$ (Merck, catalog number: 100971), storage temperature: $5 / 30{ }^{\circ} \mathrm{C}$

33. Formaldehyde solution $37 \%$ (Merck, catalog number: 104002), storage temperature: $15 / 25^{\circ} \mathrm{C}$

34. Isopropanol (Merck Millipore, catalog number:1096341000), storage temperature: $5 / 30^{\circ} \mathrm{C}$

35. Alizarin red S (Sigma-Aldrich, catalog number: A5533-25G), storage temperature: $15 / 30^{\circ} \mathrm{C}$

36. Acetic acid (Merck, catalog number: 199061), storage temperature: $15 / 25^{\circ} \mathrm{C}$

37. 3-Isobutyl-1-methylxanthine (Sigma-Aldrich, catalog number: 17018-1000MG), storage temperature: $-20^{\circ} \mathrm{C}$

38. Methanol (Merck, catalog number: 1.06009 ), storage temperature: $5 / 30{ }^{\circ} \mathrm{C}$

39. Insulin human (Sigma-Aldrich, catalog number: $12643-50 \mathrm{MG}$ ), storage temperature: $-20^{\circ} \mathrm{C}$

40. Hydrochloric acid fuming $37 \%$ (Merck, catalog number: 1.00317 ), storage temperature: $5 / 30{ }^{\circ} \mathrm{C}$

41. Indomethacin (Sigma-Aldrich, catalog number: $17378-5 \mathrm{G}$, storage temperature: $15 / 30{ }^{\circ} \mathrm{C}$ )

42. Oil red O (Sigma-Aldrich, catalog number: O0625-25G, storage temperature: $15 / 30{ }^{\circ} \mathrm{C}$ )

43. Trichome stain (Masson) Kit (Sigma-Aldrich, catalog number: HT15-1KT, storage temperature: RT)

44. Sodium pyruvate (Sigma-Aldrich, catalog number: S8636, storage temperature: $2 / 8{ }^{\circ} \mathrm{C}$ )

45. Human albumin (Institute Grifols, catalog number: A4AFC03441, storage temperature: $2 / 25^{\circ} \mathrm{C}$ )

46. Transforming growth factor- $\beta 3$ (Peprotech Inc., catalog number: $100-36 \mathrm{E}$, storage temperature: $\left.-20^{\circ} \mathrm{C}\right)$

47. 4\% Paraformaldehyde (Electron Microscopy Sciences, catalog number: 157-4-100), storage temperature: $2 / 8^{\circ} \mathrm{C}$

48. Xylene (LabSynth, catalog number: X1001.01.BJ), storage temperature: $16 / 26{ }^{\circ} \mathrm{C}$

49. Paraffin (EasyPath, catalog number: EP-21-20068A), storage temperature: $15 / 30{ }^{\circ} \mathrm{C}$

50. Eosin (Sigma-Aldrich, catalog number: HT110132), storage temperature: RT

51. Monoclonal anti-rat antibody: anti-CD29 (BD Biosciences, catalog number: 562154, storage 
temperature: $4^{\circ} \mathrm{C}$ )

52. Monoclonal anti-rat antibody: anti-CD31 (BD Biosciences, catalog number: 555027, storage temperature: $4^{\circ} \mathrm{C}$ )

53. Monoclonal anti-rat antibody: anti-CD34 (Invitrogen, catalog number: 11-0341-81, storage temperature: $4^{\circ} \mathrm{C}$ )

54. Monoclonal anti-rat antibody: anti-CD45 (BD Biosciences, catalog number: 554878, storage temperature: $4^{\circ} \mathrm{C}$ )

55. Monoclonal anti-rat antibody: anti-CD90 (BD Biosciences, catalog number: 554898, storage temperature: $4^{\circ} \mathrm{C}$ )

56. Monoclonal anti-rat antibody: anti-CD106 (BD Biosciences, catalog number: 559229, storage temperature: $4^{\circ} \mathrm{C}$ )

57. Transport medium (see Recipes)

58. Collagenase solution (see Recipes)

59. Trypsin solution (see Recipes)

60. Ascorbic acid and $\beta$-Glycerophosphate solution (see Recipes)

61. Growth medium (10\% MEM) (see Recipes)

62. Osteogenic differentiation medium (see Recipes)

63. Chondrogenic differentiation medium (see Recipes)

64. Adipocyte differentiation medium (see Recipes)

65. Dexamethasone stock solution (200 $\mu \mathrm{M})$ (see Recipes)

66. Ascorbic acid stock solution ( $20 \mathrm{mM})$ (see Recipes)

67. TGF- $\beta 3$ (see Recipes)

68. Oil red O staining (see Recipes)

\section{Equipment}

1. Scissors (Quinelato, catalog number: QT.109.14)

2. Forceps (Quinelato, catalog number: QC.301.14)

3. Erv-Mount ${ }^{\circledR}$ (EasyPath, catalog number: EP-51-05041), storage temperature: $20^{\circ} \mathrm{C}$
4. Micropipette
(Eppendorf,
catalog
numbers: 4921000028/4921000044/4921000079/4921000109/4921000117/4921000150)

5. Analytical balance M214A (BEL, catalog number: BL0003)

6. RT basic series magnetic stirrers (Thermo Fisher Scientific, catalog number: 88880009)

7. Bench meter for $\mathrm{pH}$ (Hanna, catalog number: HI5522-01)

8. Stericup quick release vacuum driven disposable filtration system (Merck, catalog number: S2GPU05RE)

9. Vacuum pump and compressor (Prismatec, catalog number: 132)

10. Airstream class II biohazard safety cabinet (Esco Micro Pte.Ltd., model: AC2-4E8)

11. Microprocessor water bath (Quimis, catalog number: Q215M) 
12. $\mathrm{CO}_{2}$ incubator (Panasonic, Panasonic/Sanyo, model: MCO-19AIC)

13. Eppendorf ${ }^{\circledR}$ Centrifuge 5702 (Sigma-Aldrich, catalog number: Z606936)

14. Axiovert 25 inverted microscope for advanced routine (Carl Zeiss)

15. Compact digital microplate shaker (Thermo Fisher Scientific, catalog number: 88880023)

16. Epoch 2 microplate spectrophotometer (BioTek, catalog number: BTEPOCH2)

17. Centrifuge 5418 R (Eppendorf, catalog number: 5401000013 )

18. Gas exhaust chapel (Lutech, catalog number: LCE-15)

19. Vertical freezer, 231 liters (Consul, catalog number: CVU26EB)

20. Refrigerator frost free, 342 liters (Consul, catalog number: CRB39AB)

21. Ultra-low freezer (Panasonic, catalog number: MDF-U500VXC-PA)

22. FACSCantoTM II (BD Biosciences, catalog number: 338962)

23. Paraffin dispenser (Oma, catalog number: IO-88)

24. Microtome (Micron, GMI, catalog number: 8243-30-0001)

\section{Software}

1. Gen 5 TS 2.06 (BioTek Instruments Inc./BioTek, https://www.biotek.com/products/softwarerobotics-software/gen5-microplate-reader-and-imager-software/)

2. BD FACSDiva ${ }^{\mathrm{TM}}$ Software v8.0.3 (https://www.bdbiosciences.com/en-us/instruments/researchinstruments/research-software/flow-cytometry-acquisition/facsdiva-software)

3. StepOne Software v2.3 (Thermo Fisher Scientific/Applied Biosystems, https://www.thermofisher.com/br/en/home/technical-resources/software-downloads/StepOneand-StepOnePlus-Real-Time-PCR-System.html)

\section{Procedure}

A. Surgical procedure

1. Euthanize the rat using isoflurane according to the local regulations.

2. Disinfect the rat by completely bathing with $1 \%$ iodized ethanol (Figure $1 \mathrm{~A}$ ) and wipe the abdomen and lower limbs with $2.5 \%$ chlorhexidine.

3. Transfer the rat in a sterile surgical drape.

4. Wear a sterile coat, mask, cap, and gloves.

5. To prevent contamination, use sterile scissors and forceps, to make a small bilateral incision in the skin of the femorotibial joint region (Figure 1B).

6. Use this incision as an access point to perform a bilateral divulsion toward the abdominal and inguinal region.

7. Make a horizontal cut to join the two previously made incisions (Figure 1B).

8. Using a \#15 scalpel blade attached to cable \#3, cut the patellar tendons, and the lateral and medial collateral ligaments bilaterally to expose the joint capsules. 
9. Perform joint capsule divulsion bilaterally.

10. Remove the muscle tissue to expose the anterior part of the femur (Figure 1C).

11. Cut the remaining ligaments and disarticulate the femoral hip joint.

12. Remove the femur, and quickly clean off the majority of muscle and connective tissues attached to the bone.

13. Transfer the femur to a $50-\mathrm{ml}$ conical tube containing $15 \mathrm{ml}$ of transport medium.

14. Retract the skin from the abdominal and inguinal regions (Figure 1D).

15. Carefully remove all adipose tissue without puncturing the abdominal wall and transfer it to a $50-\mathrm{ml}$ conical tube containing $15 \mathrm{ml}$ of transport medium.

16. Take the conical tubes containing the fat tissue and femurs to the laminar flow hood.
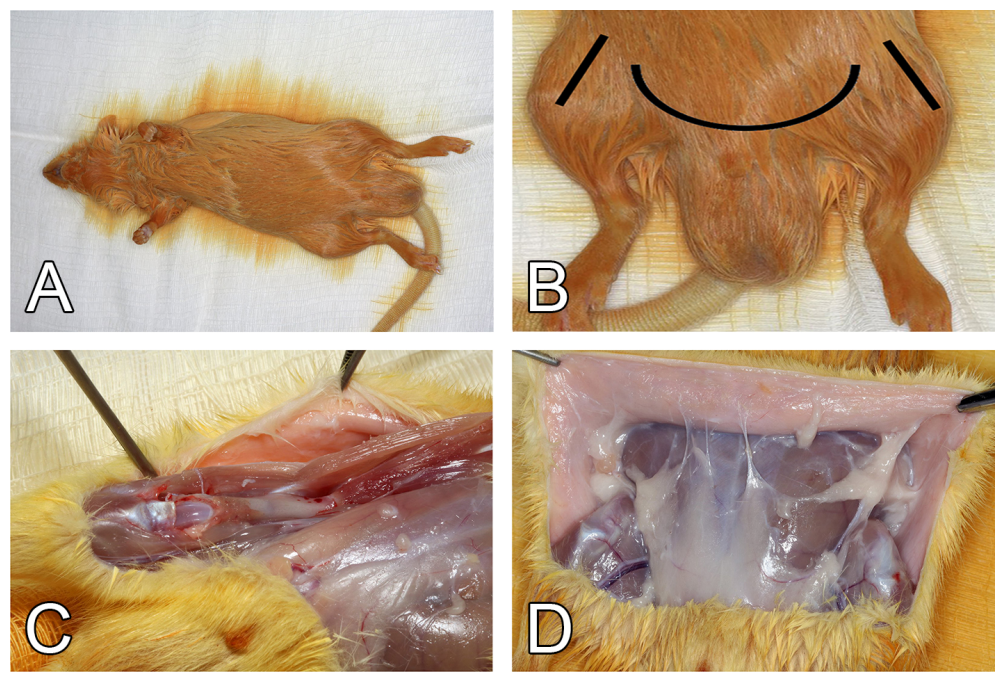

Figure 1. Surgical procedures for harvesting the femur and adipose tissue of a Wistar rat weighing 150-200 g. A. Disinfection of the animal with $1 \%$ iodized ethanol after euthanasia. B. Schematic representation of the incisions. C. Muscle removal and femur exposure. D. Skin retraction and exposure of the abdominal and inguinal adipose tissues.

B. BM-MSC isolation and culture procedures

1. Transfer the femurs from the conical tubes to a glass tissue culture dish filled with $70 \%$ ethanol.

2. Within $1 \mathrm{~min}$, remove the remaining connective tissue with sterile scissors, forceps and a \#15 scalpel blade.

3. Transfer the femurs to a new glass tissue culture dish filled with $2.5 \%$ chlorhexidine.

4. Within $1 \mathrm{~min}$, clean the remaining connective tissue with sterile scissors, forceps and a \#15 scalpel blade (Figure 2A).

5. Transfer the femurs to new conical tubes containing $15 \mathrm{ml}$ of transport medium and incubate for 15 min at RT.

6. Again, transfer the femurs to a new conical vial containing $15 \mathrm{ml}$ transport medium and incubate for 15 min at RT. 
7. Lastly, transfer the femurs to a new conical vial containing $15 \mathrm{ml}$ transport medium and incubate for 15 min at RT.

8. Transfer the contents of this conical tube to a glass tissue culture dish.

9. Fill a $20-\mathrm{ml}$ syringe with growth medium and attach a $21 \mathrm{G}$ needle.

10. Hold the femur with tweezers and cut the epiphyses using sterile scissors (Figure 2B).

11. Insert the needle of the syringe filled with growth medium into the diaphysis and flush all bone marrow into a new 50-ml conical tube (Figure $2 \mathrm{C}$ ).

12. Centrifuge this tube for $5 \mathrm{~min}$ at $600 \times g$ at RT.

13. Discard the supernatant and resuspend the pellet in new growth medium ( $2 \mathrm{ml}$ per femur).

14. Transfer $2 \mathrm{ml}$ of this suspension in a $75 \mathrm{~cm}^{2}$ cell culture flask filled with $10 \mathrm{ml}$ of growth medium.

15. Incubate this flask in an incubator at $37{ }^{\circ} \mathrm{C}$ in a humidified atmosphere containing $5 \% \mathrm{CO}_{2}$ and $95 \%$ air.

16. After $24 \mathrm{~h}$, gently rinse the flask three times with $1 \times$ PBS and replace with fresh growth medium.

17. Change the culture medium every 2 days until the cells grow to $70 \%$ confluence.

Note: After 7 days of culture in growth medium, approximately $5 \times 10^{6} \mathrm{MSCs}$ were generated from each femur of each animal.
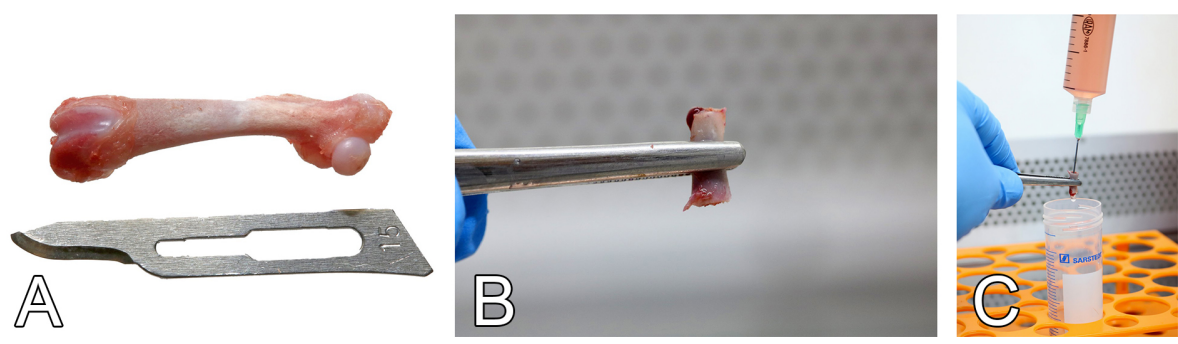

Figure 2. The harvesting of bone marrow from femur. A. Cleaned femur. B. Marrow cavity exposure after epiphyseal sectioning. C. Bone marrow flushing with growth medium using a needle and a syringe.

C. AT-MSC isolation and culture procedures

1. Transfer the adipose tissue from the $50-\mathrm{ml}$ conical tube to a glass tissue culture dish filled with $1 x$ PBS to rinse the tissue.

2. Transfer the adipose tissue to a new glass tissue culture dish (Figure 3A).

3. Use sterile scissors to mince the adipose tissue into small pieces, around 1-2 $\mathrm{mm}^{3}$ (Figure 3B).

4. Transfer the minced pieces to a $50-\mathrm{ml}$ conical tube containing $20 \mathrm{ml}$ of collagenase solution (Figure 3C).

5. Place the tube in a water bath for $40 \mathrm{~min}$ at $37^{\circ} \mathrm{C}$, with shaking.

6. Add $20 \mathrm{ml}$ of growth medium to the $50-\mathrm{ml}$ conical tube containing the adipose tissue and collagenase solution.

7. Centrifuge the conical tube containing the adipose tissue, collagenase solution, and growth medium for $5 \mathrm{~min}$ at $600 \times \mathrm{g}$. 
8. Discard the supernatant and resuspend the pellet in new growth medium (5 $\mathrm{ml}$ per adipose tissue removed from 1 animal).

9. Transfer $5 \mathrm{ml}$ of this suspension into a $75 \mathrm{~cm}^{2}$ cell culture flask filled with $10 \mathrm{ml}$ of growth medium.

10. Incubate this flask in an incubator at $37^{\circ} \mathrm{C}$ in a humidified atmosphere containing $5 \% \mathrm{CO}_{2}$ and $95 \%$ air.

11. After $24 \mathrm{~h}$, gently wash the flask three times with $1 \times$ PBS and replace with fresh growth medium.

12. Replace the culture medium every 2 days until cells are $70 \%$ confluent.

Notes:

a. After 7 days of culture in growth medium, approximately $5 \times 10^{6} \mathrm{MSCs}$ were generated from the adipose tissue of each animal.

b. Typically, within 7 days, MSCs reach $70 \%$ of confluence and are ready to be used in subsequent experiments (Figure 4).
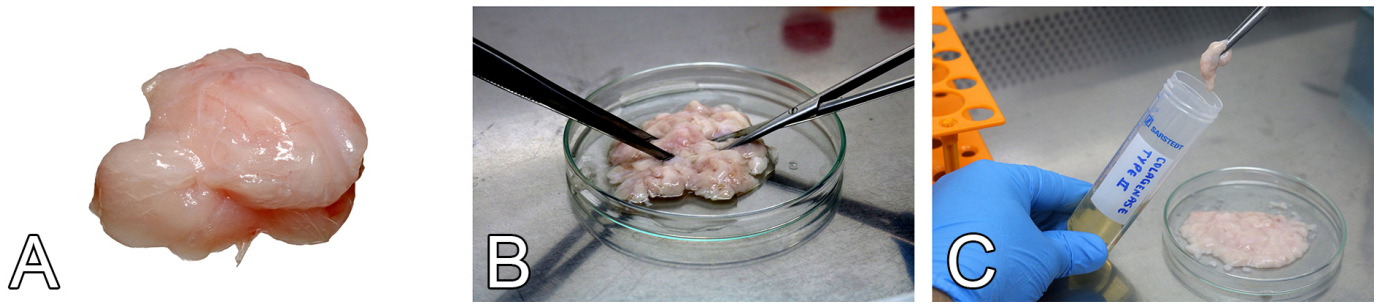

Figure 3. The enzymatic digestion of abdominal and inguinal adipose tissue. A. Harvested adipose tissue. B. Mincing of adipose tissue into small pieces using sterile scissors and tweezers. C. Transfer adipose tissue pieces to collagenase type II solution for enzymatic digestion and cell isolation.
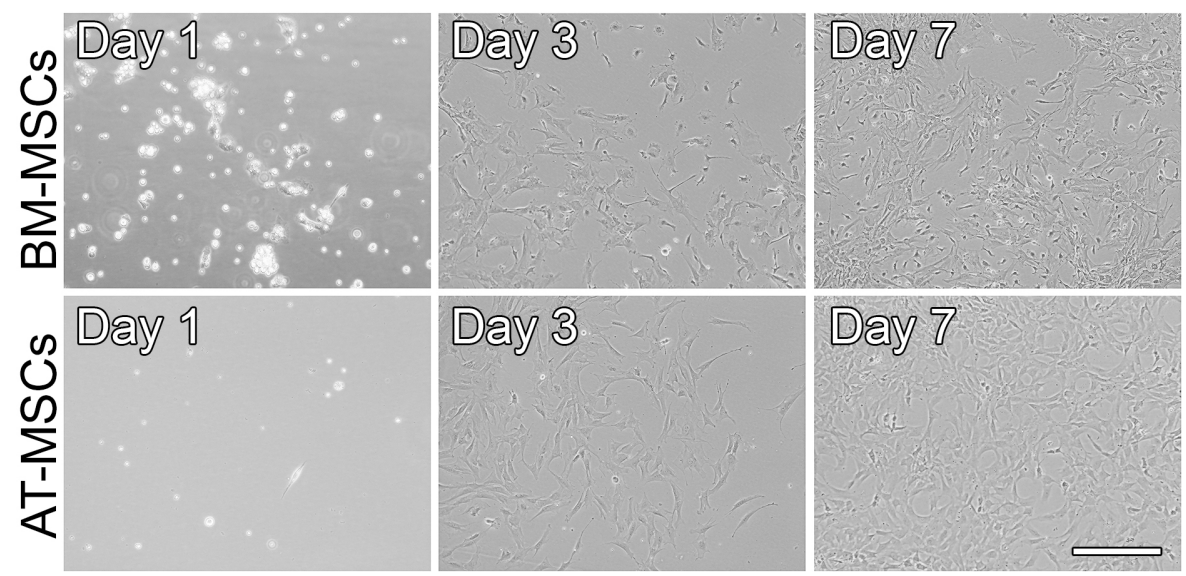

Figure 4. Phase-contrast micrographs showing the morphology of BM-MSCs and AT-MSCs that were cultured in growth medium and on polystyrene dishes for up to 7 days. After $24 \mathrm{~h}$, both BM-MSCs and AT-MSCs have attached to the polystyrene dish, and their morphology is round/oval. As the cells were cultured, they proliferated and became elongated, polygonal, and spindle-shaped. Scale bar $=100 \mu \mathrm{m}$. 


\section{Characterization of BM-MSCs and AT-MSCs}

1. Wash the flask three times with 1x PBS.

2. Add $5 \mathrm{ml}$ of trypsin solution into the flask and incubate for $5 \mathrm{~min}$ at $37^{\circ} \mathrm{C}$.

3. Add $2.5 \mathrm{ml}$ of fresh growth medium into the flask, transfer the cell suspension into a $50-\mathrm{ml}$ conical tube, and centrifuge for $5 \mathrm{~min}$ at $600 \times \mathrm{g}$.

4. Discard the supernatant.

5. Wash the cell pellet once with $1 \times$ PBS.

6. Centrifuge the cell suspension for $5 \mathrm{~min}$ at $600 \times \mathrm{g}$.

7. Discard the supernatant.

8. Add $5 \mathrm{ml}$ of $1 \times$ PBS to the cell pellet and mix the cell suspension.

9. Count the cells in a hemocytometer (Neubauer Chamber).

10. Adjust the concentration of the cell suspension to obtain a density of $2 \times 10^{5}$ cells $/ \mathrm{ml}$ with $1 \mathrm{x}$ PBS.

11. Add $1 \mathrm{ml}$ of cell suspension to each flow cytometer tube (one tube for each specific antibody, one tube for isotype control, and one tube with cells that will not be labeled with antibody).

12. Centrifuge the flow cytometer tubes for $5 \mathrm{~min}$ at $600 \times \mathrm{g}$.

13. Discard the supernatant.

14. Add $100 \mu \mathrm{l}$ of $1 \times$ PBS to the cell pellet and mix by flicking/tapping the tube.

15. Incubate each tube for $30 \mathrm{~min}$ at RT in the dark with $2 \mu \mathrm{l}$ of the following monoclonal anti-rat antibodies: anti-CD29, -CD31, -CD34, -CD45, and -CD106, directly conjugated with a fluorophore (antibody final dilution: 1:50). For monoclonal anti-rat antibody -CD90 directly conjugated with a fluorophore: dilute the antibody 1:5 in 1x PBS and then add $2 \mu$ to the cell suspension (antibody final dilution: 1:250).

16. Add $2 \mu$ of isotype control to the corresponding tube.

17. Wash the cells with $2 \mathrm{ml}$ of $1 \times$ PBS.

18. Centrifuge for $5 \mathrm{~min}$ at $600 \times \mathrm{g}$.

19. Discard the supernatant.

20. Add $0.5 \mathrm{ml}$ of formaldehyde solution (4\%) diluted to $1 \%$ in $1 \times$ PBS.

21 . Analyze the cells by flow cytometry (Figures 5 and 6 ). 


\section{BM-MSCs}
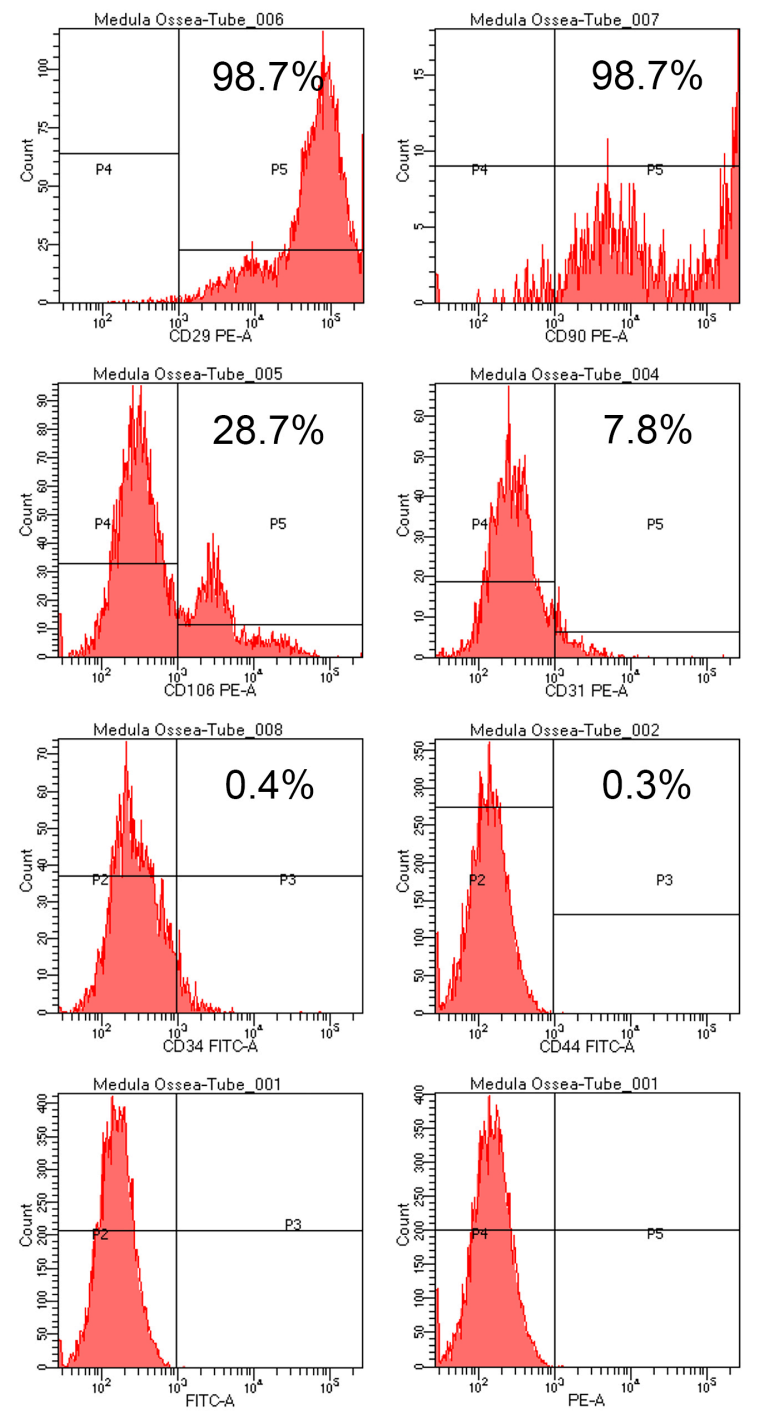

Figure 5. Flow cytometry analysis of BM-MSCs cultured in growth medium on a polystyrene culture dish for $\mathbf{7}$ days. Histograms show the expression of the surface markers CD29, CD90, CD106, CD31, CD34, and CD44 after incubation with the respective antibodies. Cells were also incubated with the isotypes FITC-A and PE-A, which were used as negative controls. A high percentage of BM-MSCs expressed CD29, CD90, and CD106 (98.7\%, 98.7\%, and $28.7 \%$, respectively) and a low percentage expressed CD31, CD34, and CD44 (7.8\%, 0.4\%, and $0.3 \%$, respectively). 


\section{AT-MSCs}
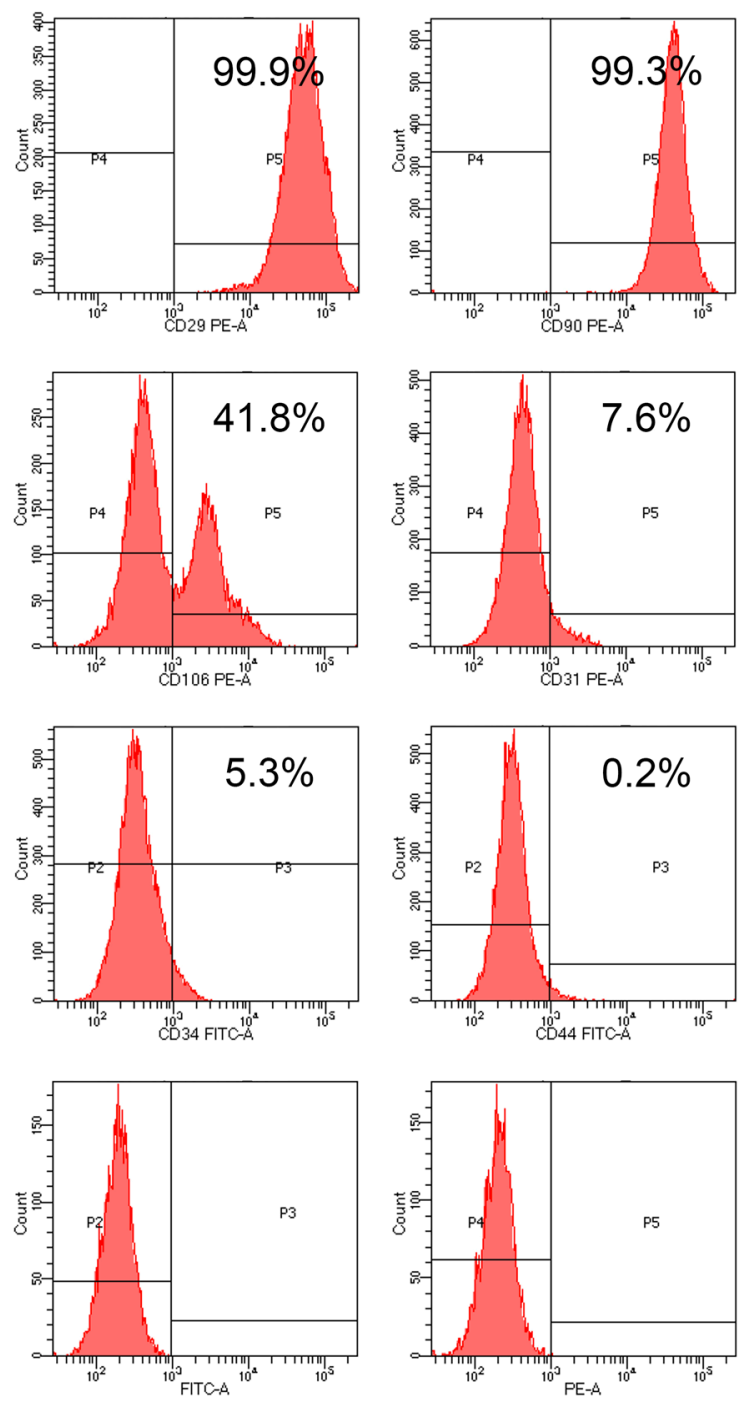

Figure 6. Flow cytometry analysis of AT-MSCs cultured in growth medium on a polystyrene dish for $\mathbf{7}$ days. Histograms show the expression of the surface markers CD29, CD90, CD106, CD31, CD34, and CD44 after incubation with the respective antibodies. Cells were also incubated with the isotypes FITC-A and PE-A, which were used as negative controls. A high percentage of AT-MSC expressed CD29, CD90, and CD106 (99.9\%, 99.3\%, and 41.8\%, respectively) and a low percentage expressed CD31, CD34, and CD44 (7.6\%, 5.3\%, and $0.2 \%$, respectively).

E. Osteoblast differentiation

1. When BM-MSCs or AT-MSCs reach $70 \%$ confluence, remove the growth medium.

2. Wash the flask three times with 1x PBS.

3. Add $5 \mathrm{ml}$ of trypsin solution into the flask and incubate for $5 \mathrm{~min}$ at $37^{\circ} \mathrm{C}$.

4. Add $2.5 \mathrm{ml}$ of fresh growth medium into the flask, transfer the cell suspension to a $50-\mathrm{ml}$ conical tube, and centrifuge for $5 \mathrm{~min}$ at $600 \times \mathrm{g}$. 
5. Discard the supernatant and resuspend the cell pellet in new growth medium.

6. Count the cells and plate them at a cell density of $2 \times 10^{4}$ cells/well in 24 -well culture plates in $1 \mathrm{ml}$ of osteogenic medium or $1 \times 10^{5}$ cells/well in 6 -well culture plates in $2 \mathrm{ml}$ of osteogenic medium.

7. Incubate the plates in an incubator at $37{ }^{\circ} \mathrm{C}$ in a humidified atmosphere containing $5 \% \mathrm{CO}_{2}$ and $95 \%$ air during the time-course of the experiment.

8. Replace the culture medium every 2 days.

9. The extracellular matrix mineralization can be observed after 21 days in culture.

F. Alizarin red staining

To confirm osteoblast differentiation, one of the methods we used is the detection of mineralized extracellular matrix by alizarin red staining.

1. Remove the culture medium from each well and gently wash the cells 3 times with $1 x$ PBS.

2. Add $10 \%$ formalin and incubate at $4{ }^{\circ} \mathrm{C}$ for $24 \mathrm{~h}$ (24-well plates-500 $\mu \mathrm{l} ; 12$-well plates-1 $\mathrm{ml} ; 6$ well plates $-2.4 \mathrm{ml}$ ).

3. Remove the $10 \%$ formalin and dehydrate the cells using increasing concentrations of ethanol $(30 \%, 50 \%, 70 \%$, and $96 \%)$ for $1 \mathrm{~h}$ each (24-well plates-500 $\mu \mathrm{l} ; 12$-well plates-1 $\mathrm{ml}$; 6 -well plates-2.4 ml).

4. Remove the $96 \%$ ethanol and incubate at RT until the wells are dry.

5. Cover the well with alizarin red staining and incubate at RT for $10 \mathrm{~min}$.

6. Wash once with deionized water and incubate at RT until the wells are dry.

7. Take macroscopic (Figure 7) and microscopic photos of the wells.

Note: Typically, BM-MSCs are more committed to osteoblast differentiation compared to AT-MSCs, as we previously observed (Abuna et al., 2016).

\section{Extracellular Matrix Mineralization}
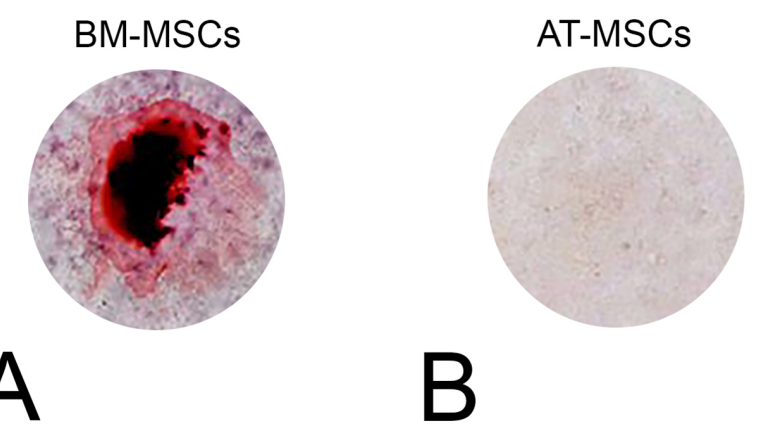

Figure 7. Mineralized extracellular matrix detected by alizarin red staining in BM-MSC and AT-MSC cultures after 21 days of culture in osteogenic medium on polystyrene dishes

G. Chondroblast differentiation

1. When BM-MSC and AT-MSC cultures reach $70 \%$ confluence, remove the growth medium.

2. Wash the flask three times with $1 \times$ PBS. 
3. Add $5 \mathrm{ml}$ of trypsin solution into the flask and incubate for $5 \mathrm{~min}$ at $37^{\circ} \mathrm{C}$.

4. Add $2.5 \mathrm{ml}$ of fresh growth medium into the flask.

5. Transfer this cell suspension to a $50-\mathrm{ml}$ conical tube and centrifuge for $5 \mathrm{~min}$ at $600 \times \mathrm{g}$.

6. Discard the supernatant.

7. Resuspend the cells in chondroblast differentiation medium at a density of $1.25 \times 10^{6} \mathrm{cell} / \mathrm{s} / \mathrm{ml}$.

8. Using a pipette, dispense $200 \mu \mathrm{l}$ aliquots of the cell suspension $\left(2.5 \times 10^{5}\right.$ cells $)$ into each well of polypropylene 96 -well plates.

9. Centrifuge the plates at $500 \times g$ for $5 \mathrm{~min}$.

10. Add $200 \mu \mathrm{l}$ of $1 x$ PBS into the empty wells to minimize the evaporation of the culture medium.

11. Incubate the plates in an incubator at $37{ }^{\circ} \mathrm{C}$ in a humidified atmosphere containing $5 \% \mathrm{CO}_{2}$ and $95 \%$ air during the time-course of the experiment.

12. After $24 \mathrm{~h}$ of incubation, cell aggregates were visible, and the chondrogenic phenotype was observed after 30 days in culture.

13. Replace the culture medium every 2 days by carefully aspirating the expired medium using a sterile $200 \mu \mathrm{l}$ pipette and adding $200 \mu \mathrm{l}$ of fresh chondrogenic medium to each well.

H. Trichrome staining

To confirm chondroblast differentiation, one of the methods we used is the detection of collagen fibers with trichrome staining.

1. Using a micropipette, remove the chondroblast differentiation medium.

2. Add $200 \mu \mathrm{l}$ of $1 \mathrm{x}$ PBS into each well.

3. Using a micropipette, remove the PBS.

4. Add $200 \mu \mathrm{l}$ of $4 \%$ paraformaldehyde for $5 \mathrm{~min}$ at RT.

5. Remove the paraformaldehyde.

6. Wash each well with $1 \times$ PBS, 2 times for 3 min each.

7. Stain the cell aggregates with eosin for $5 \mathrm{~min}$ at RT.

8. Remove the eosin and wash with 1x PBS, 2 times for 3 min each.

9. Using a $1,000 \mu \mathrm{l}$ micropipette, harvest the aggregates and transfer them to $1.5-\mathrm{ml}$ microtubes.

10. Dehydrate the cells aggregates in $300 \mu \mathrm{l}$ of a graded ethanol series $(70 \%, 80 \%, 90 \%, 95 \%$, and $100 \%, 5 \mathrm{~min}$ each) by placing them into $1.5-\mathrm{ml}$ microtubes.

11. Remove the $100 \%$ ethanol and perform three clarification steps in $300 \mu$ xylene for 3 min each.

12. Paraffin-embed the aggregates into a mold in a hot surface for $5 \mathrm{~min}$ then transfer each mold to a cold surface.

13. Cut adjacent $5 \mu \mathrm{m}$ sections using a microtome.

14. Deparaffinize the sections overnight in an incubator at $60^{\circ} \mathrm{C}$.

15. Deparaffinize the sections in three steps of xylene for 5 min each, and rehydrate the sections by incubation in an ethanol series (100\%, 95\%, 90\%, $80 \%$, and $70 \%, 3 \mathrm{~min}$ each).

16. Wash the sections with deionized water for $5 \mathrm{~min}$.

17. Stain with acid fuchsin (HT15-1) for 5 min at RT. 
18. Wash with water for $5 \mathrm{~min}$.

19. Stain with a working solution of phosphomolybdic acid (HT15-3) and phosphotungstic acid (HT15-2) for 5 min at RT.

20. Stain the sections with an aniline blue solution for 5 min at RT.

21. Remove the excess aniline blue, and add a $1 \%$ acetic acid solution for $3 \mathrm{~min}$.

22. Rinse with sections with tap water for 3 min.

23. Dehydrate sections in a graded ethanol series $(70 \%, 80 \%, 90 \%, 95 \%$, and $100 \%, 1$ min each), followed by three clarification steps in xylene for 1 min each.

24. Mount the slides using Erv-Mount ${ }^{\circledR}$.

25. Take microscopic photos of the histological sections (Figure 8).

Note: Cytoplasm is stained in red, and collagen fibers are stained in blue.
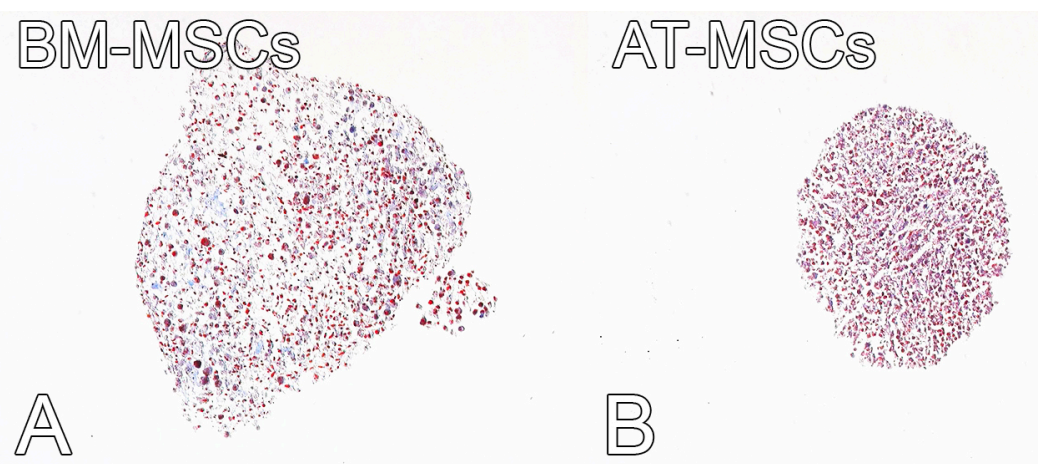

Figure 8. Collagen fibers (blue) and cytoplasm (red) detected by trichrome staining in BMMSCs and AT-MSCs cultured in chondrogenic medium on ultra-low cluster 96-well plates for 30 days. Scale bar $=100 \mu \mathrm{m}$.

I. Adipocyte differentiation

1. When BM-MSC and AT-MSC cultures reach $70 \%$ confluence, remove the growth medium.

2. Wash the flask three times with $1 \times$ PBS.

3. Add $5 \mathrm{ml}$ of trypsin solution into the flask and incubate for $5 \mathrm{~min}$ at $37^{\circ} \mathrm{C}$.

4. Add $2.5 \mathrm{ml}$ of fresh growth medium into the flask.

5. Transfer this cell suspension to a $50-\mathrm{ml}$ conical tube and centrifuge for $5 \mathrm{~min}$ at $600 \times \mathrm{g}$.

6. Discard the supernatant and resuspend the cell pellet in fresh growth medium.

7. Count the cells and plate them at a cell density of $2 \times 10^{4}$ cells/well in 24-well culture in $1 \mathrm{ml}$ of adipogenic medium plates or $1 \times 10^{5}$ cells/well in 6-well culture plates in $2 \mathrm{ml}$ of adipogenic medium.

8. Incubate the plates in an incubator at $37{ }^{\circ} \mathrm{C}$ in a humidified atmosphere containing $5 \% \mathrm{CO}_{2}$ and $95 \%$ air during the time-course of the experiment.

9. Replace the culture medium every 2 days. The intracytoplasmic lipid droplets were observed after 10 days in culture. 
J. Oil red O staining

To confirm adipocyte differentiation, one of the methods we used is the detection of intracytoplasmic lipid droplets with oil red O staining.

1. Remove the culture medium from each well.

2. Add $10 \%$ formalin and incubate for $5 \mathrm{~min}$ at RT (24-well plates-500 $\mu \mathrm{l}, 12$-well plates-1 $\mathrm{ml}, 6$ well plates $-2.4 \mathrm{ml}$ ).

3. Discard the $10 \%$ formalin and add the same volume of fresh $10 \%$ formalin. Incubate for at least $1 \mathrm{~h}$.

Note: Cells can be kept in formalin for a couple of days before staining. Wrap parafilm around the plate to prevent the cells from drying out and cover the plate with aluminum foil.

4. Remove the $10 \%$ formalin using a small transfer pipette.

5. Wash the wells with $60 \%$ isopropanol (24-well plates-500 $\mu$ l, 12 -well plates-1 $\mathrm{ml}$, 6-well plates$2.4 \mathrm{ml}$ ).

6. Let the wells dry completely.

7. Add the oil red $O$ staining working solution for $10 \mathrm{~min}$ (do not touch walls of the wells).

8. Remove the oil red $\mathrm{O}$ staining, and immediately add deionized water (repeat this step 4 times).

9. Remove all deionized water and incubate at RT to dry.

10. Image the wells using a phase-contrast microscope (Figure 9).

Note: Typically, AT-MSCs are more committed to adipogenic differentiation compared to BM-MSCs, as we previously observed (Abuna et al., 2016).

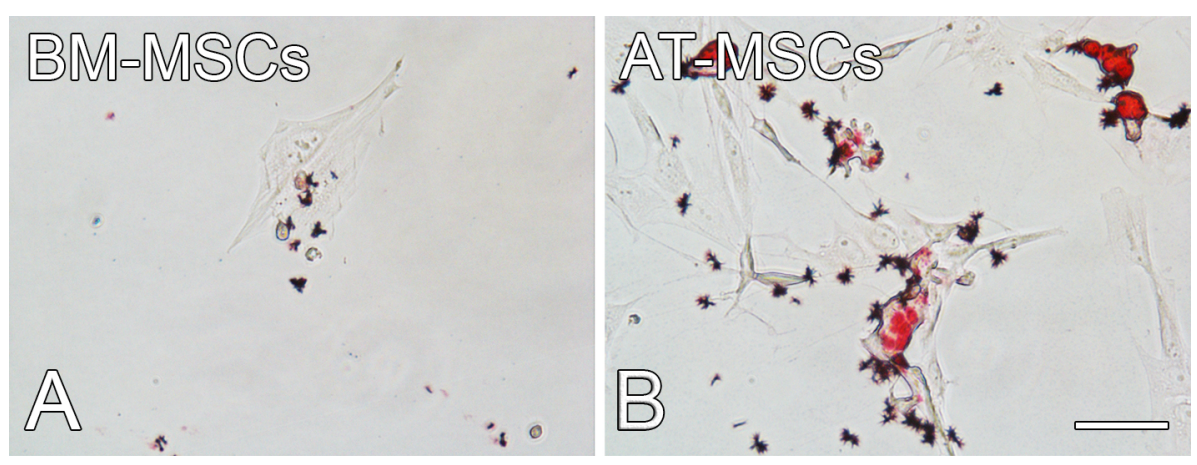

Figure 9. Intracytoplasmic lipid droplets detected by oil red O staining in BM-MSCs and AT-MSCs cultured in adipogenic medium on a polystyrene dish for 10 days. Scale bar $=$ $100 \mu \mathrm{m}$.

\section{$\underline{\text { Recipes }}$}

1. Transport medium

Note: Prepared fresh just prior to use and kept at $37^{\circ} \mathrm{C}$.

$57 \mathrm{ml}$ of alpha minimum essential medium (a-MEM)

$3 \mathrm{ml}$ of gentamycin $(50 \mu \mathrm{g} / \mathrm{ml})$

$720 \mu \mathrm{l}$ of amphotericin $\mathrm{B}(0.3 \mu \mathrm{g} / \mathrm{ml})$ 
2. Collagenase solution

Note: Prepared fresh just prior to use and placed at RT.

$15 \mathrm{mg}$ of type Il collagenase $(0.075 \%)$

$20 \mathrm{ml}$ of $1 \times \mathrm{PBS}$

Filter this solution in the laminar flow hood into a $50-\mathrm{ml}$ conical tube using a $20-\mathrm{ml}$ syringe and $0.2 \mu \mathrm{m}$ filter

3. Trypsin solution

Note: Prepared fresh just prior to use and placed at RT.

$19 \mathrm{ml}$ of trypsin $(0.25 \%)$

$500 \mu$ l of type Il collagenase $(1.3 \mathrm{mg} / \mathrm{ml})$

$1 \mathrm{ml}$ of EDTA (1 mM)

4. Ascorbic acid and $\beta$-Glycerophosphate solution

Note: Previously prepared, kept at $4{ }^{\circ} \mathrm{C}$ for up to 7 days.

$5 \mathrm{mg}$ of ascorbic acid $(5 \mu \mathrm{g} / \mathrm{ml})$

$2.16 \mathrm{~g}$ of $\beta$-glycerophosphate $(7 \mathrm{mM})$

$10 \mathrm{ml}$ of deionized water

Filter this solution in the laminar flow hood into a 50-ml conical tube using a 20-ml syringe and $0.2 \mu \mathrm{m}$ filter

5. Growth medium (10\% MEM)

Note: Previously prepared, kept at $4{ }^{\circ} \mathrm{C}$ for up to 30 days.

$360 \mathrm{ml}$ of $\mathrm{\alpha}-\mathrm{MEM}$

$40 \mathrm{ml}$ of fetal calf serum

$2 \mathrm{ml}$ of gentamycin $(50 \mu \mathrm{g} / \mathrm{ml})$

$500 \mu \mathrm{l}$ of amphotericin B $(0.3 \mu \mathrm{g} / \mathrm{ml})$

6. Osteogenic differentiation medium

Note: Previously prepared, kept at $4{ }^{\circ} \mathrm{C}$ for up to 30 days.

$400 \mathrm{ml}$ of growth medium

$4 \mathrm{ml}$ of dexamethasone $\left(10^{-7} \mathrm{M}\right)$

$1 \%$ ascorbic acid and $\beta$-glycerophosphate solution

Note: The ascorbic acid and $\beta$-glycerophosphate solution are added immediately before using the medium.

7. Chondrogenic differentiation medium

Note: Previously prepared, kept at $4{ }^{\circ} \mathrm{C}$ for up to 30 days.

$100 \mathrm{ml}$ of D-MEM

$100 \mu \mathrm{l}$ of sodium pyruvate $(100 \mathrm{mM})$

$100 \mu \mathrm{l}$ of dexamethasone $(1 \mathrm{mM})$

$250 \mu \mathrm{l}$ of ascorbic acid $(20 \mathrm{mM})$

$1 \mathrm{ml}$ of human albumin $(0.02 \%)$

$20 \mu \mathrm{l} / \mathrm{ml}$ of transforming growth factor $\beta 3$ (TGF- $\beta 3,1 \mu \mathrm{g} / \mathrm{ml}$ ). 
Note: The TGF- $\beta 3$ is added immediately before using the medium.

8. Adipocyte differentiation medium

Note: Previously prepared, kept at $4{ }^{\circ} \mathrm{C}$ for up to 30 days.

$180 \mathrm{ml}$ of D-MEM

$20 \mathrm{ml}$ of fetal calf serum (10\%)

$2 \mathrm{ml}$ of gentamycin $(50 \mu \mathrm{g} / \mathrm{ml})$

$250 \mu \mathrm{l}$ of amphotericin B $(0.3 \mu \mathrm{g} / \mathrm{ml})$

$2 \mathrm{ml}$ of dexamethasone $\left(10^{-6} \mathrm{M}\right)$

$2 \mathrm{ml}$ of 3-isobutyl-1-methylxanthine $(0.5 \mathrm{mM})$

$260 \mu$ of indomethacin $(0.1 \mathrm{M})$

$150 \mu \mathrm{l}$ of insulin $(10 \mathrm{mg} / \mathrm{ml})$

9. Dexamethasone stock solution $(200 \mu \mathrm{M})$

Note: Previously prepared, kept at $-20^{\circ} \mathrm{C}$.

Dexamethasone is dissolved at $200 \mu \mathrm{M}$ in absolute ethanol and deionized water

10. Ascorbic acid stock solution $(20 \mathrm{mM})$

Note: Previously prepared, kept at $4{ }^{\circ} \mathrm{C}$ for up to 7 days.

A stock solution of $20 \mathrm{mM}$ ascorbic acid is prepared in 1x PBS

11. TGF-B3

Note: Prepared fresh just prior to use and placed at RT.

A $1 \mu \mathrm{g} / \mathrm{ml}$ stock solution of TGF- $\beta 3$ is prepared in $1 \times$ PBS and $0.5 \%$ human albumin.

12. Oil red $O$ staining

\section{Oil red $O$ stock solution}

Note: Previously prepared, kept at RT up to 6 months.

Oil red $\mathrm{O}(700 \mathrm{mg})$ is added to $200 \mathrm{ml}$ of isopropanol, stirred overnight, and then passed through a $0.2 \mu \mathrm{m}$ filter.

\section{Oil red $O$ work solution}

Mix 6 parts of oil red $\mathrm{O}$ stock solution with 4 parts deionized water and incubate at RT for $20 \mathrm{~min}$.

\section{Acknowledgments}

This study was funded by the State of Sao Paulo Research Foundation (FAPESP, Brazil, \#2017/12622-7), National Council for Scientific and Technological Development (CNPq, Brazil, \# 305523/2013-9 and 404318/2016-9), and Coordination of Improvement of Higher Education Personnel (CAPES, Brazil). The English language review was carried out by ENAGO (www.enago.com) funded by FAPESP (\#2018/17356-6). This protocol was adapted from these works (Maniatopoulos et al., 1988; Huang et al., 2002; Penick et al.,2005). 


\section{Competing interests}

The authors declare no conflict of interest.

\section{Ethics}

All procedures performed were conducted in accordance with the ethical standards of the international, national, and/or institutional animal care guidelines. The Committee of Ethics in Animal Research of the School of Dentistry of Ribeirão Preto, University of São Paulo (\#2018.1.30.58.8) reviewed and approved all animal procedures we have done here.

\section{References}

1. Abuna, R. P., De Oliveira, F. S., Santos Tde, S., Guerra, T. R., Rosa, A. L. and Beloti, M. M. (2016). Participation of TNF- $\alpha$ in inhibitory effects of adipocytes on osteoblast differentiation. $J$ Cell Physiol 231(1): 204-214.

2. Almeida, A. L. G., Freitas, G. P., Lopes, H. B., Gimenes, R., Siessere, S., Sousa, L. G., Beloti, M. M. and Rosa, A. L. (2019). Effect of stem cells combined with a polymer/ceramic membrane on osteoporotic bone repair. Braz Oral Res 33: e079.

3. Bianco, P., Robey, P. G. and Simmons, P. J. (2008). Mesenchymal stem cells: revisiting history, concepts, and assays. Cell Stem Cell 2(4): 313-319.

4. Caplan, A. I. (1991). Mesenchymal stem cells. J Orthop Res 9(5): 641-650.

5. Fideles, S. O. M., Ortiz, A. C., Assis, A. F., Duarte, M. J., Oliveira, F. S., Passos, G. A., Beloti, M. M. and Rosa, A. L. (2019). Effect of cell source and osteoblast differentiation on gene expression profiles of mesenchymal stem cells derived from bone marrow or adipose tissue. $J$ Cell Biochem 120(7): 11842-11852.

6. Freitas, G. P., Lopes, H. B., Souza, A. T. P., Oliveira, P., Almeida, A. L. G., Souza, L. E. B., Coelho, P. G., Beloti, M. M. and Rosa, A. L. (2019). Cell therapy: effect of locally injected mesenchymal stromal cells derived from bone marrow or adipose tissue on bone regeneration of rat calvarial defects. Sci Rep 9(1): 13476.

7. Friedenstein, A. J., Chailakhjan, R. K. and Lalykina, K. S. (1970). The development of fibroblast colonies in monolayer cultures of guinea-pig bone marrow and spleen cells. Cell Tissue Kinet 3(4): 393-403.

8. Harting, M., Jimenez, F., Pati, S., Baumgartner, J. and Cox, C., Jr. (2008). Immunophenotype characterization of rat mesenchymal stromal cells. Cytotherapy 10(3): 243-253.

9. Hu, Q., Liu, M., Chen, G., Xu, Z. and Lv, Y. (2018). Demineralized bone scaffolds with tunable matrix stiffness for efficient bone integration. ACS Appl Mater Interfaces 10(33): 27669-27680. 
10. Huang, J. I., Beanes, S. R., Zhu, M., Lorenz, H. P., Hedrick, M. H., Benhaim, P. (2002). Rat extramedullary adipose tissue as a source of osteochondrogenic progenitor cells. Plast Reconstr Surg 109(3):1033-1041.

11. Lopes, H. B., Freitas, G. P., Fantacini, D. M. C., Picanço-Castro, V., Covas, D. T., Rosa, A. L. and Beloti, M. M. (2019). Titanium with nanotopography induces osteoblast differentiation through regulation of integrin $\alpha \mathrm{V} . J$ Cell Biochem 120(10): 16723-16732.

12. Maniatopoulos, C., Sodek, J., Melcher, A. H. (1988). Bone formation in vitro by stromal cells obtained from bone marrow of young adult rats. Cell Tissue Res 254(2): 317-330.

13. Nancarrow-Lei, R., Mafi, P., Mafi, R. and Khan, W. (2017). A systemic review of adult mesenchymal stem cell sources and their multilineage differentiation potential relevant to musculoskeletal tissue repair and regeneration. Curr Stem Cell Res Ther 12(8): 601-610.

14. Oliveira, F. S., Bellesini, L. S., Defino, H. L., da Silva Herrero, C. F., Beloti, M. M. and Rosa, A. L. (2012). Hedgehog signaling and osteoblast gene expression are regulated by purmorphamine in human mesenchymal stem cells. J Cell Biochem 113(1): 204-208.

15. Penick, K. J., Solchaga, L. A. and Welter, J. F. (2005). High-throughput aggregate culture system to assess the chondrogenic potential of mesenchymal stem cells. Biotechniques 39(5): 687-691.

16. Pierini, M., Dozza, B., Lucarelli, E., Tazzari, P. L., Ricci, F., Remondini, D., di Bella, C., Giannini, S. and Donati, D. (2012). Efficient isolation and enrichment of mesenchymal stem cells from bone marrow. Cytotherapy 14(6): 686-693.

17. Schrepfer, S., Deuse, T., Lange, C., Katzenberg, R., Reichenspurner, H., Robbins, R. C. and Pelletier, M. P. (2007). Simplified protocol to isolate, purify, and culture expand mesenchymal stem cells. Stem Cells Dev 16(1): 105-107.

18. Wadajkar, A. S., Santimano, S., Tang, L. and Nguyen, K. T. (2014). Magnetic-based multi-layer microparticles for endothelial progenitor cell isolation, enrichment, and detachment. Biomaterials 35(2): 654-663.

19. Zhang, Y. D., Zhao, S. C., Zhu, Z. S., Wang, Y. F., Liu, J. X., Zhang, Z. C. and Xue, F. (2017). Cx43- and smad-mediated TGF-beta/BMP signaling pathway promotes cartilage differentiation of bone marrow mesenchymal stem cells and inhibits osteoblast differentiation. Cell Physiol Biochem 42(4): 1277-1293.

20. Zuk, P. A., Zhu, M., Mizuno, H., Huang, J., Futrell, J. W., Katz, A. J., Benhaim, P., Lorenz, H. P. and Hedrick, M. H. (2001). Multilineage cells from human adipose tissue: implications for cellbased therapies. Tissue Eng 7(2): 211-228. 